\title{
PERPUSTAKAAN DAN MINAT BACA SISWA
}

\author{
Saroni \\ e-mail: inorasironi@yahoo.co.id
}

\begin{abstract}
Abstrak
Anak merupakan investasi yang paling berharga bagi setiap orang tua. Karena dengan hadirnya seorang anak akan menimbulkan berbagai harapan di dalam benak setiap orang tua. Setiap orang tua juga menginginkan anak-anak mereka cerdas dan memiliki wawasan yang luas, dan kecerdasan dapat dipupuk dalam diri anak sejak usia dini. Menumbuh kembangkan minat baca anak pada usia dini adalah dengan membaca, jika anak dapat membaca sejak usia dini, maka hal itu dapat membuka wawasan mereka lebih jauh lagi. Prestasi siswa yang tinggi merupakan dampak dari keberadaan perpustakaan di sekolah. Prestasi yang tinggi karena keterampilan siswa dalam membaca dipengaruhi oleh beberapa faktor, seperti fasilitas perpustakaan dan kinerja pustakawan yang ada di perpustakaan. Permasalahan dalam penelitian ini yaitu kurangnya fasilitas perpustakaan yang memadai, rendahnya ketrampilan pustakawan dibeberapa perpustaan sekolah.

Peranan perpustakaan sangat menunjang prestasi pendidikan di sekolah, perpustakaan sangat penting dan harus ada pada setiap sekolah. Dijenjang pendidikan pengelolaan perpustakaan harus dilaksanakan sesuai dengan tujuan dan fungsinya. Rumusan masalah karya tulis ilmiah ini adalah (1) Bagaimana deskripsi peran perpustakaan terhadap pelaksanaan program pendidikan di sekolah ? dan (2) Bagaimana deskripsi cara agar perpustakaan sekolah benar-benar dapat meningkatkan minat baca siswa? Data diperoleh melalui studi kepustakaan.

Kesimpulan penelitian ini adalah (1) Peranan perpustakaan sangat menunjang prestasi pendidikan di sekolah; (2) perpustakaan sangat penting dan harus ada pada setiap sekolah di semua jenjang pendidikan; dan (3) Pengelolaan perpustakaan harus dilaksanakan sesuai dengan tujuan dan fungsinya. Rekomendasi yang diajukan adalah (1) sebaiknya perpustakaan dikelola sesuai dengan tujuan dan fungsinya dan (2) Peran pengelola perpustakaan / pustakawan yang profesional hendaknya mendapatkan bekal yang cukup sehingga menjadi pustakawan yang handal dan profesional.
\end{abstract}

\section{Keywords : Perpustakaan, Minat Baca Siswa}

\section{PENDAHULUAN}

Anak merupakan investasi yang paling berharga bagi setiap orang tua. Karena dengan hadirnya seorang anak akan menimbulkan berbagai harapan di dalam benak setiap orang tua. Setiap orang tua juga menginginkan anak-anak mereka cerdas dan memiliki wawasan yang luas, dan kecerdasan dapat dipupuk dalam diri anak sejak usia dini. Menumbuh kembangkan minat baca siswa pada usia dini adalah dengan membaca, jika anak dapat membaca sejak usia dini, maka hal itu dapat membuka wawasan mereka lebih jauh lagi.

Membaca merupakan kegiatan yang produktif untuk dilakukan, mengingat membaca begitu penting untuk dilaksanakan dalam kehidupan manusia. Namun perlu diingat orang tua dalam melaksanakannya untuk tetap 
memperhatikan perkembangan dari anak, sehingga tidak terdapat unsur pemaksaan. Minat membaca kali pertama harus ditanamkan melalui pendidikan dan kebiasaan keluarga. Dalam pendidikan dalam hal ini adalah peran dari perpustakaan.

Perpustakaan menurut UU Perpustakaan pada Bab I pasal 1 menyatakan Perpustakaan adalah institusi yang mengumpulkan pengetahuan tercetak dan terekam, mengelolanya dengan cara khusus guna memenuhi kebutuhan intelektualitas para penggunanya melalui beragam cara interaksi pengetahuan.

Ilmu pengetahuan dan teknologi selalu berkembang dan mengalami kemajuan, sesuai dengan perkembangan zaman dan perkembangan cara berpikir manusia. Bangsa Indonesia sebagai salah satu negara berkembang tidak akan bisa maju selama belum memperbaiki kualitas sumber daya manusia bangsa kita. Kualitas hidup bangsa dapat meningkat jika ditunjang dengan sistem pendidikan yang mapan. Dengan sistem pendidikan yang mapan, memungkinkan kita berpikir kritis, kreatif, dan produktif.

Dalam UUD 1945 disebutkan bahwa negara kita ingin mewujudkan masyarakat yang cerdas. Untuk mencapai bangsa yang cerdas, harus terbentuk masyarakat belajar. Masyarakat belajar dapat terbentuk jika memiliki kemampuan dan keterampilan mendengar dan minat baca yang besar. Apabila membaca sudah merupakan kebiasaan dan membudaya dalam masyarakat, maka jelas buku tidak dapat dipisahkan dari kehidupan sehari-hari dan merupakan kebutuhan pokok yang harus dipenuhi.

Dalam dunia Pendidikan, buku terbukti berdaya guna dan tepat guna sebagai salah satu sarana pendidikan dan sarana komunikasi. Dalam kaitan inilah perpustakaan dan pelayanan perpustakaan harus dikembangkan sebagai salah satu instalasi untuk mewujudkan tujuan mencerdaskan kehidupan bangsa.
Perpustakaan merupakan bagian yang vital dan besar pengaruhnya terhadap mutu pendidikan. Dalam arti tradisional, perpustakaan adalah sebuah koleksi buku dan majalah. Walaupun dapat diartikan sebagai koleksi pribadi perseorangan, namun perpustakaan lebih umum dikenal sebagai sebuah koleksi besar yang dibiayai dan dioperasikan oleh institusi, dan dimanfaatkan oleh masyarakat yang ratarata tidak mampu membeli sekian banyak buku atas biaya sendiri. Tetapi, dengan koleksi dan penemuan media baru selain buku untuk menyimpan informasi, banyak perpustakaan kini juga merupakan tempat penyimpanan dan/atau akses ke map, cetak atau hasil seni lainnya, mikrofilm, mikrofiche, tape audio, CD, LP, tape video dan DVD, dan menyediakan fasilitas umum untuk mengakses gudang data CDROM dan internet.

Perpustakaan dapat juga diartikan sebagai kumpulan informasi yang bersifat ilmu pengetahuan, hiburan, rekreasi, dan ibadah yang merupakan kebutuhan hakiki manusia. Oleh karena itu perpustakaan modern telah didefinisikan kembali sebagai tempat untuk mengakses informasi dalam format apapun, apakah informasi itu disimpan dalam gedung perpustakaan tersebut atau tidak. Dalam perpustakaan modern ini selain kumpulan buku tercetak, sebagian buku dan koleksinya ada dalam perpustakaan digital (dalam bentuk data yang bisa diakses lewat jaringan komputer). Peran Perpustakaan merupakan upaya untuk memelihara dan meningkatkan efisiensi dan efektifitas proses belajar-mengajar. Perpustakaan yang terorganisir secara baik dan sisitematis, secara langsung ataupun tidak langsung dapat memberikan kemudahan bagi proses belajar mengajar di sekolah tempat perpustakaan tersebut berada. Hal ini, terkait dengan kemajuan bidang pendidikan dan dengan adanya perbaikan metode belajar-mengajar yang dirasakan tidak bisa dipisahkan dari masalah 
penyediaan fasilitas dan sarana pendidikan.

Istilah - istilah pustaka, pustakawan, kepustakawanan, dan ilmu perpustakaan. Secara harfiah, perpustakaan sendiri masih dipahami sebagai sebuah bangunan fisik tempat menyimpan buku - buku atau bahan pustaka. Untuk itu, pada pembahasan kali ini akan dikupas secara mendalam tentang pengantar umum perpustakaan yang meliputi : pengertian perpustakaan, maksud dan tujuan pendirian perpustakaan, jenis - jenis perpustakaan, peranan, tugas, dan fungsi perpustakaan, aktifitas pokok perpustakaan, dan perpustakaan sebagai disiplin ilmu.

Berkaitan dengan judul tersebut, maka masalahnya dapat dirusmuskan sebagai berikut :

1. Bagaimana peran perpustakaan terhadap pelaksanaan program pendidikan di sekolah?

2. Bagaimana cara agar perpustakaan sekolah benar-benar dapat meningkatkan prestasi siswa ?

\section{KERANGKA TEORI}

Perpustakaan merupakan bagian intergral dari lembaga pendidikan sebagai tempat kumpulan bahan pustaka, baik berupa buku maupun bukan buku. pembahasan meliputi minat baca siswa, pengertian perpustakaan, tujuan perpustakaan, fungsi perpustakaan dan sumbangan perpustakaan terhadap pelaksanaan program pendidikan.

\section{Minat Baca Siswa}

Minat diartikan sebagai momen dari kecenderungan terarah secara intensif kepada suatu objek yang dianggap penting, Kartini Kartono dalam Nurbiyanti (1980:78). Minat dapat dikelompokkan sebagai sifat atau sikap yang memiliki kecenderungankecenderungan atau tendensi tertentu. Minat dapat mempresentasikan tindakan- tindakan, minat tidak dapat dikelompokkan sebagai

pembawa tetapi sifatnya dapat diusahakan, dipelajari, dan dikembangkan.

Menurut Ibrahim Bafadal (1992:192), telah dijelaskan bahwa minat sebagai berikut:

a) Minat bukan hasil pembawaan manusia tetapi dapat dibentuk atau diusahakan, dipelajari, dan dikembangkan.

b) Minat itu dapat dihubungkan untuk maksud-maksud tertentu untuk bertindak.

c) Secara sempit, minat itu diasosiasikan dengan keadaan sosial seseorang dan emosi seseorang.

d) Minat itu biasa membawa inisiatif dan mengarahkan kepada kelakuan atau tabiat manusia.

Mengenai pengertian membaca, banyak ahli mengemukakan pendapatnya tentang membaca. Membaca merupakan kegiatan komplek dan sengaja, dalam hal ini berupa proses berfikir yang didalamnya terdiri dari berbagai aksi pikir yang bekerja secara terpadu mengarah kepada satu tujuan yaitu memahami makna paparan tertulis secara keseluruhan (Ibrahim Bafadal, 1992:193). Membaca adalah proses psikologi yang melibatkan penglihatan, gerak mata, ingatan pengetahuan mengenai kata yang dapat dipahami dan pengalaman membacanya", Suwaryono Wiryodijoyo dalam Nurbiyanti (1989:78). Membaca adalah kegiatan yang dilakukan berupa penerjemahan simbol atau huruf ke dalam kata dan kalimat yang memiliki makna bagi seseorang", Bram dan Dickey dalam Darmono (2007:215).

\section{Perpustakaan}

Perpustakaan diartikan sebuah ruangan atau gedung yang digunakan untuk menyimpan buku dan terbitan lainnya yang biasanya disimpan menurut tata susunan tertentu yang digunakan 
pembaca bukan untuk dijual. Ada dua unsur utama dalam perpustakaan, yaitu buku dan ruangan. Namun, di zaman sekarang, koleksi sebuah perpustakaan tidak hanya terbatas berupa buku-buku, tetapi bisa berupa film, slide, atau lainnya, yang dapat diterima di perpustakaan sebagai sumber informasi. Kemudian semua sumber informasi itu diorganisir, disusun teratur, sehingga ketika kita membutuhkan suatu informasi, kita dengan mudah dapat menemukannya.

Perpustakaan menurut Sutarno (2006:11-12) adalah suatu bagian dari gedung atau bangunan, atau gedung itu sendiri, yang berisi

buku-buku koleksi, yang disusun dandiatur sedemikian rupa sehingga mudah dicari dan dipergunakan apabila sewaktu-waktu diperlukan oleh pembaca. Menurut Keputusan Menteri Pendidikan dan kebudayaan tertanggal 11 Maret No. 0103/0/1981, perpustakaan sekolah adalah sebagai pusat kegiatan belajarmengajar, pusat penelitian sederhana, pusat baca, guna menambah ilmu pengetahuan dan rekreasi. Berdasarkan beberapa pengertian dari perpustakaan tersebut maka dapat disimpulkan bahwa perpustakaan sekolah adalah segala sesuatu yang digunakan, ditempati, dan dinikmati guna menunjang pengorganisasian koleksi pustaka yang diatur menurut sistem tertentu dalam suatu ruang, merupakan bagian integral dalam proses belajar mengajar serta membantu mengembangkan bakat dan minat siswa, dalam penyelenggaraannya diperlukan seorang pustakawan yang dapat diambil dari salah seorang guru.

Dengan memperhatikan keterangan di atas, dapat disimpulkan bahwa perpustakaan adalah suatu unit kerja yang berupa tempat menyimpan koleksi bahan pustaka yang diatur secara sistematis dan dapat digunakan oleh pemakainya sebagai sumber informasi. Perpustakaan sebagai lembaga pendidikan dan lembaga penyedia informasi akan memiliki kinerja yang baik apabila didukung dengan manajemen yang memadai, sehingga seluruh aktivitas lembaga akan mengarah para upaya pencapaian tujuan yang telah dicanangkan.

\section{Tujuan Perpustakaan Sekolah.}

Tujuan perpustakaan adalah untuk membantu masyarakat dalam segala umur dengan memberikan kesempatan dengan dorongan melalui jasa pelayanan perpustakaan agar mereka:

a) Dapat mendidik dirinya sendiri secara berkesimbungan;

b) Dapat tanggap dalam kemajuan pada berbagai lapangan ilmu pengetahuan, kehidupan sosial dan politik;

c) Dapat memelihara kemerdekaan berfikir yang konstruktif untuk menjadi anggota keluarga dan masyarakat yang lebih baik;

d) Dapat mengembangkan kemampuan berfikir kreatif, membina rohani dan dapat menggunakan kemempuannya untuk dapat menghargai hasil seni dan budaya manusia;

e) Dapat meningkatkan tarap kehidupan seharihari dan lapangan pekerjaannya;

f) Dapat menjadi warga negara yang baik dan dapat berpartisipasi secara aktif dalam pembangunan nasional dan dalam membina saling pengertian antar bangsa;

g) Dapat menggunakan waktu senggang dengan baik yang bermanfaat bagi kehidupan pribadi dan sosial.

Tujuan utama penyelenggaraan perpustakaan sekolah adalah meningkatkan mutu pendidikan bersamasama dengan unsur-unsur sekolah lainnya. Sedangkan tujuan lainnya adalah menunjang, mendukung, dan melengkapi semua kegiatan baik kurikuler, kokurikuler dan ekstra kurikuler, di samping dimaksudkan pula dapat membantu 
menumbuhkan minat dan mengembangkan bakat murid serta memantapkan strategi belajar mengajar.Namun secara operasional tujuan perpustakaan sekolah bila dikaitkan dengan pelaksanaan program di sekolah, diantaranya adalah :

a) Memupuk rasa cinta, kesadaran, dan kebiasaan membaca.

b) Membimbing dan mengarahkan teknik memahami isi bacaan.

c) Memperluas pengetahuan para siswa.

d) Membantu mengembangkan kecakapan berbahasa dan daya pikir para siswa dengan menyediakan bahan bacaan yang bermutu.

e) Membimbing para siswa agar dapat menggunakan dan memelihara bahan pustaka dengan baik.

f) Memberikan dasar-dasar ke arah studi mandiri.

g) Memberikan kesempatan kepada para siswa untuk belajar bagaimana cara menggunakan perpustakaan dengan baik, efektif dan efisien, terutama dalam menggunakan bahan-bahan referensi.

h) Menyediakan bahan-bahan pustaka yang menunjang pelaksaanan program kurikulum di sekolah baik yang bersifat kurikuler, kokurikuler, maupun ekstra kurikuler.

\section{Fungsi Perpustakaan Sekolah}

Berdasarkan tujuan perpustakaan sekolah, maka dapat dirumuskan beberapa fungsi perpustakaan, sebagai berikut :

\section{Fungsi Edukatif.}

Yang dimaksud dengan fungsi edukatif adalah perpustkaan menyediakan bahan pustaka yang sesuai dengan kurikulum yang mampu membangkitkan minat baca para siswa, mengembangkan daya ekspresi, mengembangkan kecakapan berbahasa, mengembangkan gaya pikir yang rasional dan kritis serta mampu membimbing dan membina para siswa dalam hal cara menggunakan dan memelihara bahan pustaka dengan baik.

\section{Fungsi Informatif.}

Yang dimaksud dengan fungsi informatif adalah perpustakaan menyediakan bahan pustaka yang memuat informasi tentang berbagai cabang ilmu pengetahuan yang bermutu dan uptodate yang disusun secara teratur dan sistematis, sehingga dapat memudahkan para petugas dan pemakai dalam mencari informasi yang diperlukannya.

\section{Fungsi Administratif}

Yang dimaksudkan dengan fungsi administratif ialah perpustakaan harus mengerjakan pencatatan, penyelesaian dan pemrosesan bahan-bahan pustaka serta menyelenggarakan sirkulasi yang praktis, efektif, dan efisien.

\section{Fungsi Rekreatif.}

Yang dimaksudkan dengan fungsi rekreatif ialah perpustakaan disamping menyediakan buku-buku pengetahuan juga perlu menyediakan buku-buku yang bersifat rekreatif (hiburan) dan bermutu, sehingga dapat digunakan para pembaca untuk mengisi waktu senggang, baik oleh siswa maupun oleh guru.

\section{Fungsi Penelitian}

Yang dimaksudkan dengan fungsi penelitian ialah perpustakaan menyediakan bacaan yang dapat dijadikan sebagai sumber / obyek penelitian sederhana dalam berbagai bidang studi.

\section{METODE PENELITIAN}

Dalam penelitian ini, peneliti memunculkan latar belakang dan masalahmasalah yang actual. Dengan kata lain, masalah yang menjadi topik penelitian ini adalah masalah yang benar-benar sedang terjadi. Sehubungan dengan hal itu, maka peneliti menggunakan analisis kualitatif yang bersifat deskriptif.

Deskriptif berarti menyarankan bahwa penelitian yang dilakukan semata-mata hanya berdasarkan fakta yang ada dan 
fenomena yang memang secara empiris hidup pada penutur-penuturnya, sehingga yang dihasilkan berupa perian bahasa yang bisa dikatakan sifatnya seperti potret paparan apa adanya. Perian deskriptif itu tidak mempertimbangkan benar salahnya penggunaan bahasa oleh penuturpenuturnya, hal iyu merupakan cirinya yang utama dan terutama (Sudaryanto, 1992:62).

\section{PEMBAHASAN}

Bila diperhatikan secara jenih, maka perpustakan sekolah sesungguhnya memberikan sumbangan terhadap pelaksanaan program pendidikan di sekolah. Sumbangan/peranan perpustakaan antara lain :

a) Perpustakaan merupakan sumber ilmu pengetahuan dan pusat kegiatan belajar.

b) Perpustakaan merupakan sumber ide-ide baru yang dapat mendorong kemauan para siswa untuk dapat berpikir secara rasional dan kritis serta memberikan petunjuk untuk mencipta.

c) Perpustakaan akan memberikan jawaban yang cukup memuaskan bagi para siswa, sebagai tuntutan rasa keingintahuan terhadap sesuatu, benar-benar telah terbangun.

d) Kumpulan bahan pustaka (koleksi) di perpustakaan memberika kesempatan membaca bagi para siswa yang mempunyai waktu dan kemampuan yang beraneka ragam.

e) Perpustakaan memberikan kesempatan kepada para siswa untuk mempelajari cara mempergunakan perpustakaan yang efisien dan efektif.

f) Perpustakaan akan membantu para siswa dalam meningkatkan dalam kemampuan membaca dan memperluas perbendaharaan bahasa. g) Perpustakaan dapat menimbulkan cinta membaca, sehingga dapat mengarahkan selera dan apresiasi siswa dalam pemilihan bacaan.

h) Perpustakaan memberikan kepuasan akan pengetahuan di luar kelas.

i) Perpustakaan merupakan pusat rekreasi yang dapat memberikan hiburan yang sehat.

j) Perpustakaan memberikan kesempatan kepada para siswa dan guru untuk mengadakan penelitian.

k) Perpustakaan merupakan batu loncatan bagi para siswa untuk melanjutkan kebiasaan hidup membaca di sekolah yang lebih tinggi.

1) Kegairahan/minat baca siswa yang telah dikembangkan melalui perpustakaan sangat berpengaruh positif terhadap prestasi belajarnya.

m) Bila minat membaca sudah tumbuh dan berkembang pada diri siswa, maka perpustakaan juga dapat mengurangi jajan anak, yang ini biasanya dapat berpengaruh negatif terhadap kesehatan anak.

n) Bahkan perpustakaan juga bagi anak-anak dapat menjauhkan diri dari tindakan kenakalan, yang bisa menimbulkan suasana kurang sehat dalam hubungan berteman diantara mereka.

\section{SIMPULAN}

Berdasarkan uraian bahasan perpustakaan dan minat baca siswa dapat disimpulkan bahwa :

a) Peranan perpustakaan sangat menunjang prestasi pendidikan di sekolah.

b) Perpustakaan sangat penting dan harus ada pada setiap sekolah di semua jenjang pendidikan.

c) Pengelolaan perpustakaan harus dilaksanakan sesuai dengan tujuan dan fungsinya 


\section{Rekomendasi}

Bertolak dari peranan perpustakaan yang begitu banyak sumbangsihnya dalam pelaksanaan program pendidikan di sekolah, penyusun memberikan saran sebagai berikut:

a) Sebaiknya perpustakaan dikelola sesuai dengan tujuan dan fungsinya.

b) Peran pengelola perpustakaan/ pustakawan yang profesional hendaknya mendapatkan bekal yang cukup sehingga menjadi pustakawan yang handal dan profesional.

\section{DAFTAR PUSTAKA}

Bafadal, Ibrahim. 1992. Pengelolaan Perpustakaan Sekolah. Bandung: Bumi Aksara.

Darmono. 2007. Perpustakaan Sekolah. Jakarta: PT Grasindo.
Keputusan Menteri Pendidikan dan Kebudayaan tertanggal 11 Maret No. 01030/1981 Tentang "Perpustakaan Sekolah".

NS Sutarno. 2006. Manajemen

Perpustakaan suatu Pendekatan Praktik.

Sudaryanto. 1992. Aneka Konsep Kedatangan Lingual dalam Linguistik. Yogyakarta: Gajah Mada University Press.

Sutarno, NS. 2006. Perpustakaan dan Masyarakat. Jakarta: Yayasan Obor Indonesia.

Sulistio, Basuki. 1993. Pengantar Ilmu Perpustakaan. Jakarta: Universitas Terbuka. 10

Yulia Yuyu dkk. 2010. Pengembangan Koleksi. 